\title{
Genome-editing opportunities to enhance cattle productivity in the tropics
}

\author{
Luiz Sergio de Almeida Camargo ${ }^{1 *+}$ (iD and Jorge Fernando Pereira ${ }^{2+}$
}

\begin{abstract}
The livestock performance in tropical regions has been limited by environmental conditions that causes heat stress and favors the development of parasites and diseases, impairing animal health. Heat stress disturbs animal homeostasis and affects animal production and fertility, with negative impacts on meat and milk quality. Flies and ticks proliferate easily under hot-humid weather, which makes difficult the control of their population, resulting in an increased parasitism. Tropical pastures usually have high dry matter production, but it is challenging to keep high production and quality under different environmental conditions throughout the year, constraining animal performance. Several strategies have been adopted in an attempt to overcome such hurdles in the tropical regions, but definitive solutions are yet to be implemented. In the last 20 years, biotechnologies, such as in vitro embryo production and genomic selection, have played an important role on cattle production in tropical countries. Genome editing (GnEd) is the novel tool in the toolbox for cattle production. GnEd with genomic selection offers the opportunity to boost the genetic gain in breeding programs of tropical cattle in fewer generations. It can be applied for disease resistance, to control parasite population, and to improve pasture quality and tolerance to biotic and abiotic stresses, favoring animal health and nutrition. Moreover, there is a perspective for the use of GnEd to control cattle methane emission by editing genes of methanogens present in the rumen. Although GnEd can already be applied to improve some traits, studies are still required for the identification of candidate genes in animals, tropical pastures, parasites, and microorganisms that can be targeted by gene editing in order to offer a robust contribution to the improvement of cattle production in the hot regions. Some examples of the use of GnEd are presented in this review, focusing on new perspectives of using GnEd to increase cattle production under the challenges of the tropical environments.
\end{abstract}

Keywords: Livestock, Heat stress, Milk, Pasture, Gene modification

\section{Introduction}

The world population is projected to reach 9.7 billion people in 2050, with most of the population growth estimated for countries located in tropical or subtropical regions, as Africa and Asia (United Nations, Department of Economic and Social Affairs 2019). The demand

\footnotetext{
*Correspondence: luiz.camargo@embrapa.br

${ }^{\dagger}$ Luiz Sergio de Almeida Camargo and Jorge Fernando Pereira contributed equally to this study

${ }^{1}$ Animal Reproduction and Biotechnology Laboratory, Embrapa Dairy Cattle, Rua Eugenio do Nascimento, Juiz de Fora, MG 610, Brazil

Full list of author information is available at the end of the article Luiz Sergio de Almeida Camargo and Jorge Fernando Pereira contributed equally to this study
}

of food for this growing population needs to be fulfilled without increasing the pressure on land usage. Thus, increased food productivity is mandatory. However, crop and animal production in Asian and Africans countries have been limited by several factors, being the environmental conditions critical for livestock, as most countries are located between the tropics of Cancer and Capricorn. High temperature and humidity in the tropics cause several impacts on animal production, health and welfare, reducing productivity (Oke et al. 2021). Hot-humid weather is also an issue for Latin American regions located in the tropical belt, where the climate is a barrier to increase productivity (Garcia et al. 2015).

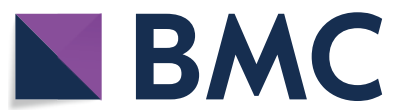

Aurts) 2022. Open Access This article is licensed under a Creative Commons Attribution 4.0 International License, which permits use, sharing, adaptation, distribution and reproduction in any medium or format, as long as you give appropriate credit to the original author(s) and the source, provide a link to the Creative Commons licence, and indicate if changes were made. The images or other third party material in this article are included in the article's Creative Commons licence, unless indicated otherwise in a credit line to the material. If material is not included in the article's Creative Commons licence and your intended use is not permitted by statutory regulation or exceeds the permitted use, you will need to obtain permission directly from the copyright holder. To view a copy of this licence, visit http://creativecommons.org/licenses/by/4.0/. The Creative Commons Public Domain Dedication waiver (http://creativeco mmons.org/publicdomain/zero/1.0/) applies to the data made available in this article, unless otherwise stated in a credit line to the data. 
One of the main problems in the tropics is heat stress, which disturbs animal homeostasis affecting the metabolic and hormonal status. To face this challenge, the body has to make physiological adjustments that lead to an increase in heat loss and reduction of heat production (dos Santos et al. 2021). All those adjustments have a price that is usually associated with low fertility and performance on milk and meat production. Heat stress can also have a direct impact on cell viability, as seen in lymphocytes, oocytes and embryos when exposed in vitro to high temperatures and humidity (Camargo et al. 2019; Paula-Lopes et al. 2003). Unfortunately, heat stress is not the only problem for cattle in the tropics. Ectoparasites, diseases, pasture quality and production throughout the year are also issues that require much attention. Ticks and tick-borne diseases can be found in tropical region as well as horn and screwworm flies, resulting in economic losses (Grisi et al. 2014; Jongejan and Uilenberg 2004). Also, tropical forages have high capacity of dry matter production, but there are several traits needing improvements (Pereira et al. 2018; Simeão et al. 2021), which constrain animal performance.

No single solution for livestock in the tropics is at hand. Capacity building, herd management, cooling strategies, vaccinations, and breeding programs are strategies that have being used with a range of success, depending of the country. In the last decades, biotechnologies have assumed an important role on cattle production. In vitro embryo production (IVP) and genomic selection have been applied with success (Panetto et al. 2020; Viana et al. 2018) in some tropical countries. The arising of genome editing ( $\mathrm{GnEd}$ ) opened new opportunities for cattle breeding as it can be used to fix target alleles for monogenic traits, delete undesirable recessive alleles and increase the frequency of favorable alleles for polygenic traits (Hickey et al. 2016). For instance, editing of 20 loci of a target trait plus genomic selection could double the genetic gain over 20 generations when compared with genomic selection alone (Jenko et al. 2015). Indeed, GnEd can offer possibilities of changes that would take generations to occur in cattle. Single or multiple alleles associated with a desirable trait in a specific breed can be moved (introgression) to another breed without crossbreeding. Moreover, if the allele or alleles are already in the target breed but at a low frequency, that can be increased in one or two generations because the editing can be performed in thousand zygotes from different cows and sires in a IVP laboratory. Such possibility, along with the simplicity and low cost, makes GnEd a powerful tool to cattle in the tropics and an alternative to conventional breeding (Fig. 1). For instance, alleles associated to a better body management of heat (heat tolerance) found in a tropical-adapted but low productive performance breed could be introduced to a heat-sensitive high productive performance breed. Frequency of alleles associated to tick tolerance could be increased or introduced into a given breed. The application of GnEd in the tropics is not only for animal breeding. Tropical pastures can be edited to increase drought tolerance and digestibility to provide good quality forages to feed animals along the year. Ticks and flies can be edited so that their population could be controlled in order to decrease the impact on animal health. Resistance to infectious diseases can also be created through changes in pathways from infection to the spread of the pathogen. Methanogen archaeas in the rumen can be edited to reduce methane production, minimizing the greenhouse effect caused by rumen gas emission. Thus, this review is focused on current status and perspectives for the use of genome editing tools to increase cattle productivity in tropical environments.

\section{GnEd to address heat stress concerns}

Heat stress is a major problem in the tropics and subtropics. It results in lower productivity that increases the demand for land along the years; one concern is that the situation can become worse in tropical lands with the climate change (Henry et al. 2018). A study estimated losses in milk production that could reach 1.7 billion/year in 2050 and 2.2 billion in 2080 due to global warming in North America (Mauger et al. 2015). The heat stress in the USA can lead to losses of US\$ 1.2 billion/year with a reduction in milk production, especially in the southern states, when compared to a stress-free environment (Key and Sneeringer 2014). In fact, climate change may contribute to further accentuate the effect of temperature on reducing the productivity of cattle herds (Nardone et al. 2010; Thornton et al. 2009), especially in tropical regions already affected by excessive heat and that hold a large bovine population. The impact of global changes on milk production in some Brazilian states can lead to an increase in heat stress that would be intensified in both warmer and colder months, and in the worst-case scenario, milk production could be limited to low productivity animals due to excessive heat (Silva et al. 2010). It is estimated that every $1{ }^{\circ} \mathrm{C}$ of temperature rise above thermal comfort may represent a reduction of $1.15 \mathrm{~kg}$ of milk/day in a warm climate region (Hayhoe et al. 2004). In addition to lower performance, heat stress can have effects on milk and meat quality (Summer et al. 2019; Zhang et al. 2020). Heat stress can also decrease productivity by decreasing reproductive efficiency, characterized by lower gamete and embryo viability, reduced conception rates and increased calving interval (Hansen 2009; Rensis and Scaramuzzi 2003; Takahashi 2012).

The effects of heat stress are more evident in European cattle (Bos taurus taurus), such as the Holstein and 


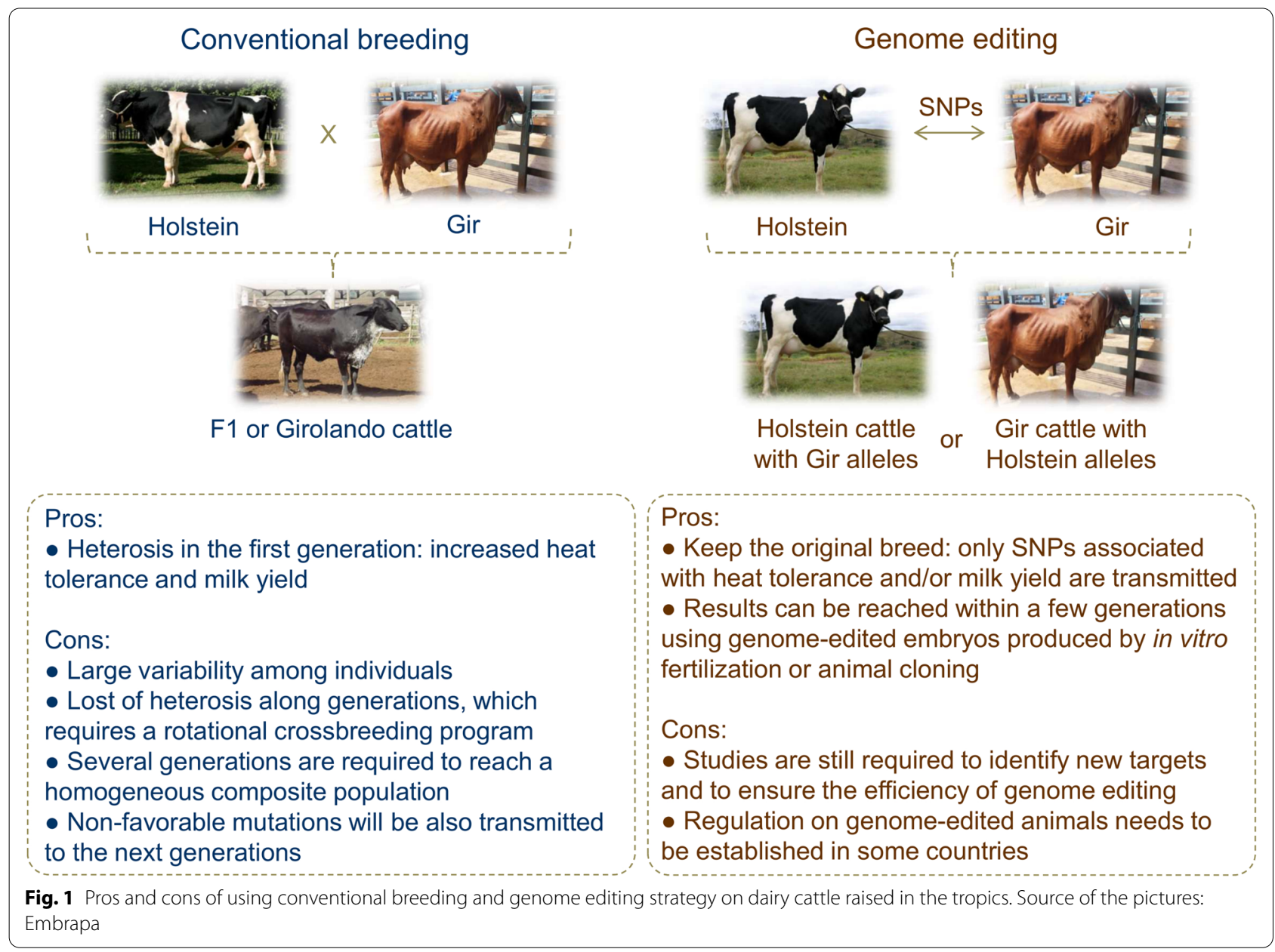

Angus breeds, than those of Asian origin (Hansen 2020; Paula-Lopes et al. 2003), such as Gir and Nellore breeds, also known as zebu breeds (Bos taurus indicus). However, $B$. taurus indicus cattle are less productive than $B$. taurus taurus (Ahmed and El Amin 1997; Guimarães et al. 2002). On the other hand, B. taurus taurus animals are more sensitive to heat stress, compromising reproductive and productive performances (Hansen 2015). One solution has been crossbreeding to take advantage of heterosis (Miranda and Freitas 2009). For instance, Holstein $(\mathrm{H}) \times$ Gir $(\mathrm{G})$ crossbred cows have been the main source of milk production in several regions of Brazil, forming the synthetic breed Girolando (Freitas et al. 2013), established as $5 / 8 \mathrm{H} \times \mathrm{G}$, also encompassing other grades of blood, from $1 / 4$ to $7 / 8 \mathrm{H} \times \mathrm{G}$. However, a large genetic variability exists in Girolando cattle, with animals with various degrees of heat tolerance (Carvalheira et al. 2021). Thus, it will take several generations of Girolando cattle to reach a homogeneous population due to the long interval between generations. Furthermore, crossbreeding ends up not only transmitting genes and mutations of desired traits, but also unwanted traits that sooner or later may arise and compromise animal performance or health.

An alternative to circumvent the problem of heat stress without crossing breeds is the GnEd technology. With this technology, polymorphisms associated with heat tolerance can be transferred from one breed to another without requiring crossbreeding. This is the case of the slick hair coat (SLICK) locus located in the prolactin hormone receptor $(P R L R)$ gene. The SLICK haplotype identified in heat-adapted breeds found in Central and South America results in animals with short and fine hair and with a better regulation of body temperature (Huson et al. 2014; Olson et al. 2003). The SLICK locus is found in Senepol cattle (Mariasegaram et al. 2007), a synthetic breed better adapted to hot climate. In 15/16 Holstein $x$ Senepol cows, the presence of the SLICK locus resulted in animals with thinner and shorter hair, minimizing the loss in milk production in the summer (Dikmen et al. 2014). A mutation (C>T) in exon 11 (SLICK2) of the PRLR gene was found in Limonero and Carora cattle 
(Porto-Neto et al. 2018). The slick phenotype and mutation can also be found in Caracu cows, a European breed brought to Brazil from Portugal in the beginning of colonization and well-adapted to subtropical climate (Camargo; personal communication). Slick mutation can be introduced in the PRLR gene of thermo-sensitive breeds to reduce heat stress when animals are exposed to high temperatures and humidity (Hansen 2020).

Other possibility to alleviate heat stress is to reduce the effects of sunlight on heat production in the animal body. Black or dark coat colors absorb more solar radiation and increases the solar heat gain (Hillman et al. 2001; Walsberg 1988). Red-and-white Holstein cows have lower rectal temperatures than black-and-white Holstein cows in the hot season (Isola et al. 2020). Also in the hot season, Holstein cows with coats predominantly black yielded less milk than those with coats predominantly white (Anzures-Olvera et al. 2019). Thus, reducing the size of black spots or diluting the black color on the coat of dairy cows can be an alternative to reduce the effects of heat stress on animal performance. A deletion of three base pairs in the pre-melanossomal protein 17 gene is found in diluted-colored Highland cattle (Schmutz and Dreger 2013). By the introgression of that mutation in Holstein embryos, it was possible to dilute the black color in a calf, producing a grey-and-white animal (Laible et al. 2020).

Although those two examples can already be targeted by GnEd, they probably are not sufficient to address the effects of heat stress. New alleles associated with heat tolerance need to be identified in order to be targeted by GnEd. For that, genome-wide association studies (GWAS) with fine-mapping analysis using distinct cattle populations are required to identify genomic regions that could be associated with the regulation of body temperature. For example, B. taurus indicus cattle are known to be more heat tolerant than $B$. taurus taurus cattle, and such distinction may be related to differences not only in production performance between breeds, but also in physiological adaptations that contribute to the regulation of heat gain and loss in B. taurus indicus cows (Hansen 2020). Recently, a GWAS was performed in Brazil using information from Girolando cattle aiming to identify genomic regions that could be associated with variations in vaginal temperature during hot-humid seasons (Camargo, personal communication). More than 35,000 data points of vaginal temperature were recorded within $48 \mathrm{~h}$ from 763 Girolando cows during the summer, and GWAS was performed using random regression models for vaginal temperature, with gene ontology (GO) enrichment analysis being performed by Cytoscape software. Genetic variance over 0.4 was found in chromosome 15, 17 and 23 in a 10-consecutive SNPs window. Four genes with biological functions on adaptive thermogenesis were identified in chromosome 15: uncoupling protein $2(U C P 2)$ and $3(U C P 3)$, caseinolytic mitochondrial matrix peptidase chaperone subunit $B$ $(C L P B)$, and phosphodiesterase 2A (PDE2A). GO analysis revealed relevant enriched pathways as a response to superoxide $(U C P 3)$ and to oxygen radical $(U C P 3)$, mitochondrial transport (UCP2, UCP3 and $P D E 2 A)$, response to temperature stimulus (CLPB, $U C P 2$ and $U C P 3)$, and response to heat $(C L P B)$ and cold (UCP2 and UCP3). Even though preliminary studies and a fine-mapping analysis are still required, such data suggest that causal mutations associated with the regulation of body temperature can be found in other candidate genes and, once the function is well-established, they can be potentially targeted by GnEd.

\section{GnEd to increase quality and milk yield in tropical cattle breeds}

Milk is one of the main food sources for people living in the tropics. It has not only a nutritional importance, but also an economic and social significance for large and smallholders. While large famers need to produce milk efficiently in order to make the farming activity profitable, smallholders can milk cows to feed the family but also sell the excess of milk to dairy companies for some revenue. Both cases need cows producing milk with a reasonable efficiency in a hot weather. Unfortunately, most of Bos taurus indicus breeds do not produce milk efficiently (Ahmed and El Amin 1997; Guimarães et al. 2002). Among several reasons, and compared with Bos taurus taurus, the lack of genetic selection appears to stand out as one of the main reasons for low productivity. For instance, the genetic breeding program for Brazilian Gir dairy cattle started only in 1985, and despite the contribution in the increase in milk yield (Panetto et al. 2020), the productivity is still lower than in European dairy breeds.

Traditional genetic selection programs based on progeny tests take long to show robust results due to long generational intervals and low intensity of selection. Although genomic selection has been used in genetic breeding programs for some Bos taurus indicus breeds (Panetto et al. 2020), there is now a chance to enhance genetic improvement in tropical cattle. The GnEd offers the opportunity to introduce SNPs associated with milk yield in the genome of thousands of embryos in just one generation. Being a polygenic trait, increasing milk yield or quality using GnEd will not be an easy task and will depend on the identification of SNPs using GWAS and fine-mapping studies. One issue may be the introduction of multiple SNPs in the genome of preimplantation embryos. Although this has not been tested in cattle yet, 
it is possible to introduce multiples site-specific mutations in the genome using genome editing (Cong et al. 2013; McCarty et al. 2020; Sansbury et al. 2019).

While multiplex genome editing is no feasible in cattle, GnEd can be used to introduced specific single-mutations associated to milk yield in the genome of tropical cattle. A mutation that results in an amino acid change (phenylalanine $>$ tyrosine) in exon 8 of the growth hormone receptor (GHR) gene of Holstein, Jersey and Ayrshire breeds is associated with an increased milk yield (Blott et al. 2003; Rahmatalla et al. 2011; Viitala et al. 2006). One of the roles of growth hormone (GH) is the stimulation of milk and protein production, which can occur indirectly through systemic changes, such as in food intake, blood flow and nutrient sharing for the mammary gland (Bauman 1999), but may also involve direct mechanisms in the epithelial cells of the mammary gland (Svennersten-Sjaunja and Olsson 2005). Receptors of GH have been identified in the mammary gland (PlathGabler et al. 2001), and an in vitro study with bovine mammary gland cells showed that GH can stimulate the expression of several genes of major milk proteins, such as caseins and alpha- lactalbumin and influence milk production (Zhou et al. 2008), which indicates the functionality of the GHR. This same specific mutation has not been reported for Bos taurus indicus cattle (El-Nahas 2018; Ramesha et al. 2016) and thus, it is a potential target for editing in order to contribute to milk production in those breeds.

Another possible target is a point mutation in the stearoyl-coenzyme A desaturase (SCD1) gene. This enzyme is responsible for the endogenous synthesis of conjugated linoleic acid (CLA) C18: 2 cis9, trans11 in the milk fat of lactating cows (Corl et al. 2001). CLA has been reported to be beneficial to human health, showing anticarcinogenic, anti-obese and anti-hypertensive properties (Dilzer and Park 2012; Koba and Yanagita 2014; Ringseis and Eder 2009). A single nucleotide modification in the $S C D 1$ gene results in a non-synonymous codon change leading to an amino acid change $(A>V)$ in the enzyme, causing an increased ratio of CLA without affecting the index of unsaturated fat in milk in Holstein cows (Schennink et al. 2008). The frequency of variant $\mathrm{V}$ in the Holstein cattle population was found to be low in herds of Netherlands (6.7\%), (Schennink et al. 2008) and Canada (13.6\%) (Kgwatalala et al. 2007). In the Jersey breed, a low frequency $(5.2 \%)$ for variant $\mathrm{V}$ was also reported (Kgwatalala et al. 2007). In a study with a limited number of Gir cows, some SNPs were found, but none of them with the modification that results in the variant V (Freitas et al. 2013), suggesting that its frequency in Gir cattle is also low. In this case, GnEd can be used to increase the proportion of CLA in milk fat in tropical dairy cows, benefiting consumers and aggregating value to the dairy products. Certainly, increase of milk yield and quality in tropics with GnEd will not be possible if animals are not appropriated fed. In the tropical regions cattle are mainly raised on pastures and those need to efficiently feed the animal all over the year.

\section{GnEd to control tropical parasites}

Tropical regions have as a feature an abundance of flies, mosquitos and ticks that benefit from the high humidity and hot weather to proliferate. Some of those ectoparasites can cause a direct effect on the animal, debilitating its health with consequences on growth, weight gain and milk yield, decreasing productivity (Rashid et al. 2019). One of those pests is the New World screwworm (Cochliomyia hominivorax) that infests the Caribbean and South American regions, with the larvae causing primary myiasis in cattle, although it can also parasite other warm-blood animals (Costa-Júnior et al. 2019). Screwworms were eradicated from USA and Central America using the sterile insect technique (SIT), where male sterile flies are released systematically to the environment to compete with native fertile males (Wyss 2006). The sterilization is achieved by radiation of pupae and require a mass production of quality insects to be sterilized (Scott et al. 2017). Although it was successful, the eradication screwworm program is expensive and challenging as it requires a mass production of male flies. The GnEd offers an opportunity to develop new pest control technologies that could be associated to SIT program. By disrupting the transformer (tra) gene, which controls sex determination in $C$. hominovorax, it was possible to knockout the gene to induce masculinization of surviving $\mathrm{XX}$ flies. With that, for instance, it will be possible to use GnEd to produce only males for the $C$. hominovorax SIT program (Paulo et al. 2019), which can contribute to reduce cost and to establish an effective program in South America.

Tick and tick-borne diseases are among the major constraint to livestock production in tropical and subtropical regions. While ticks can cause irritation, allergy and other toxic conditions that debilitate the organism, babesiosis and anaplasmoses, two of pathogens transmitted by ticks, increase the morbidity and mortality (Jongejan and Uilenberg 2004). A study with beef cattle detected potential candidate genes and significant SNPs associated with low tick infestation (Mota et al. 2018). A GWAS with a F2 population of Holstein x Gir cattle identified genes involved in the immunological functions, as Triggering receptor expressed on myeloid cells (TREM) 1 and 2 and Cluster of differentiation 83 (CD83) genes that were associated to tick resistance. Most of animals resistant to tick infestation presented both maternal and paternal alleles originated from Gir breed (Otto et al. 2018). 
Those sorts of studies are helping to pave the road toward the identification of causative mutations that can be targeted by GnEd in a near future. On the other hand, GnEd can be applied to control tick population, as shown in flies (Paulo et al. 2019) and mosquitos (Feng et al. 2021; Macias et al. 2020), by manipulating the tick genome in order to reduce population and capacity of infestation (de la Fuente 2018). An approach called Receptor-Mediated Ovary Transduction of Cargo (ReMOT Control) was developed to genetically manipulate mosquitoes in order to overcome the need of embryo injection and it can be extended to other invertebrates (Chaverra-Rodriguez et al. 2018), making the GnEd process easier and less costly in those species.

\section{GnEd to improve the production and quality of tropical pastures}

The feeding system influences the quality of meat, milk, and other dairy products (Delgado-Pertínez and Horcada 2021; Moscovici Joubran et al. 2021). In a number of countries, most cattle are raised on pasture-based systems, which are viewed as more environmentally and animal welfare friendly (Moscovici Joubran et al. 2021). That is not different in tropical countries, where grazing is the most common way of cattle production. Environmental conditions in the tropics are not usually fit for temperate grasses and tropical forage grasses from different genera are grown as pastures, including Guinea grass (Megathyrsus maximus syn. Panicum maximum), elephant grass (Cenchrus purpureus syn. Pennisetum purpureum) and species of Urochloa (syn. Brachiaria). In Brazil, near $80 \%$ of the pastureland is cultivated with Urochola spp. and $M$. maximus represents around $10 \%$ of the cultivated pasture (Jank et al. 2014). In the past few years, cultivars of elephant grass are being well accepted by farmers, with one cultivar (cv BRS Capiaçu) cultivated in over 700 thousand ha only in four years (EMBRAPA 2020). Even though these tropical forage grasses represent a significant proportion of the pastures in the tropical region, there are research priorities and breeding goals that are not easily achieved by conventional breeding (Pereira et al. 2018; Simeão et al. 2021). There are opportunities for GnEd studies in tropical forage grasses to improve traits as digestibility, drought tolerance, spittlebug resistance, and shade tolerance (Fig. 2).

Digestibility can be defined as the proportion of forage biomass that can be digested and adsorbed by the animal. Biomass digestibility is dependent upon several components including cellulose, lignin, hemicellulose, and cell wall proteins (Pauly and Keegstra 2016). There have been efforts in order to elucidate the molecular mechanisms associated with biomass digestibility in tropical forage grasses. Two markers and candidate genes involved in the biosynthesis of cell wall molecules were found to be associated with digestibility in elephant grass (Rocha et al. 2019). Also in elephant grass, 39 markers were associated with eight feed quality traits, including acid detergent lignin and in vitro organic matter digestibility (Muktar et al. 2022). In $U$. ruziziensis, three genes associated with cell wall components were found to be highly confident loss-of-function alleles that may confer increased digestibility (Hanley et al. 2021). After confirming the role of such genes, GnEd may target them to improve the digestibility of tropical forage grasses.

Drought tolerance is the ability to sustain biomass or grain production under limited amount of water. This is an important trait because tropical forage grasses are perennial plants that eventually will face periods of drought under field conditions (Fig. 2). Cultivars that are able to keep higher forage production and quality under limited water availability are desirable. There is genetic variation for drought tolerance among tropical forage grasses and the molecular basis for that variation has been investigated. For instance, genes associated with cell wall metabolism may be important components of the drought tolerance in Brachiaria (Jones et al. 2021). In elephant grass, the dry matter produced per litre of water was used to evaluate water use efficiency (WUE) across 84 genetically diverse genotypes (Muktar et al. 2022). WUE was strongly correlated $(>0.97)$ with total fresh weight and total dry weight, and several molecular markers associated with these traits have been found in several chromosomes (Muktar et al. 2022). For U. brizantha, the mechanisms of adaptation to water stress seems to be osmoregulation and deep roots (Santos et al. 2013). Since a large proportion of the soils in the tropics have acidic subsoils where aluminium ( $\mathrm{Al})$ stress is a major problem, the use of $\mathrm{Al}$ tolerant tropical forage grasses may lead to deeper rooting. Some genes for $\mathrm{Al}$ tolerance are available for $U$. decumbens (Salgado et al. 2017). Based on the subsequent confirmation of the importance of these genes for drought tolerance, WUE and Al tolerance, GnEd may be used to improve drought tolerance in tropical forage grasses.

Other important traits that can be targeted by GnEd in tropical forage grasses are spittlebug resistance and shade tolerance. However, the molecular basis for these traits have been less investigated. Improving spittlebug resistance in tropical forage grasses may lead into consideration some genomic regions and candidate genes found in $U$. decumbens (Ferreira et al. 2019). It is because many tropical forage grasses are susceptible to spittlebugs. The attack of spittlebugs is virtually inexistent during the dry season and it impacts forage productivity and quality 


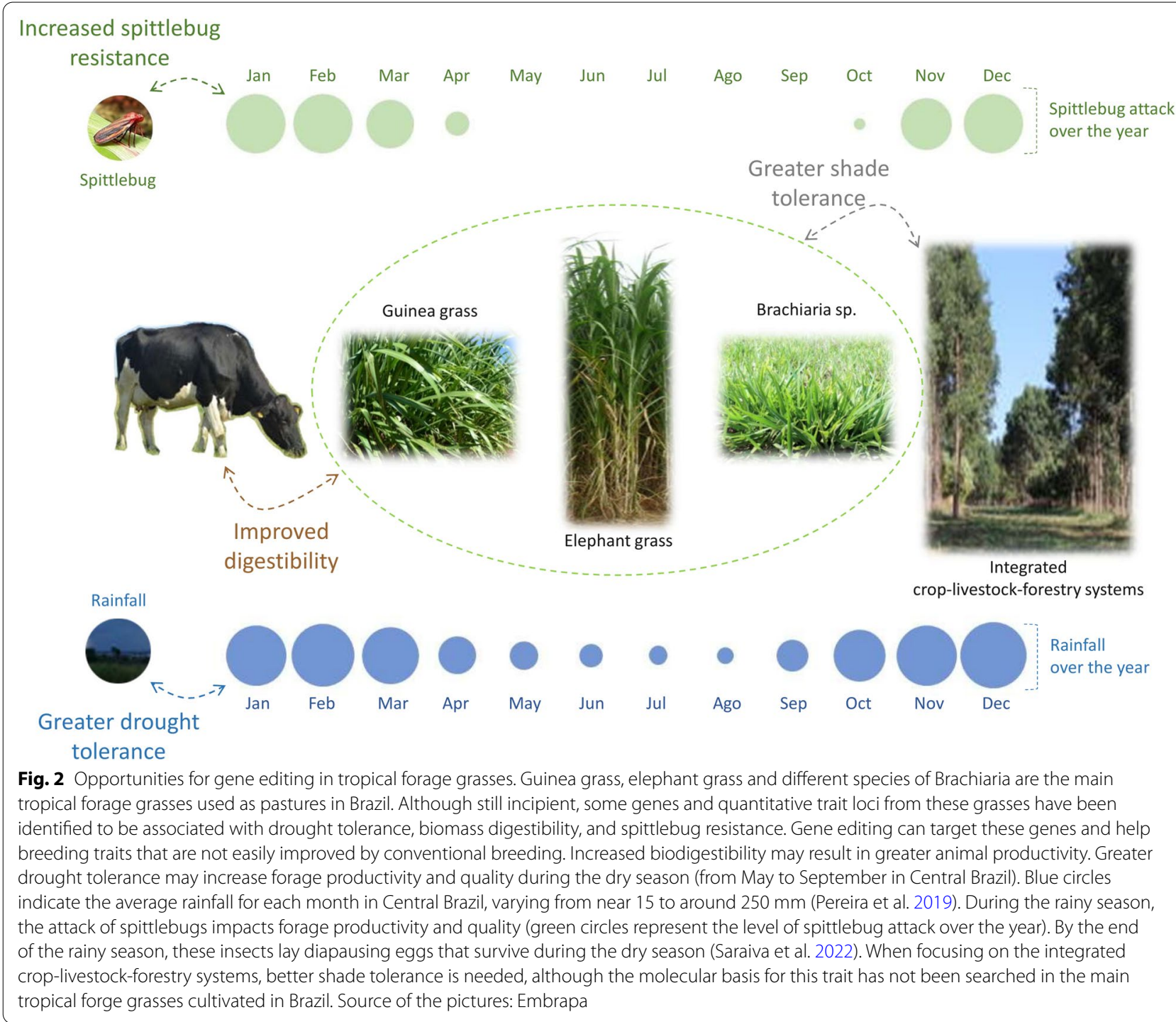

during the rainy season (Fig. 2). Increased shade tolerance is desired in tropical forage grasses targeted to be used in the integrated crop-livestock-forestry systems, as $U$. ruziziensis. In this system, forages are grown alongside crops and trees with economic and environmental benefits. However, when trees became tall, shadow may impact the growth of forages. Even though there is variation for shadow tolerance among species of tropical forage grasses (Deinum et al. 1996; Guenni et al. 2008), the molecular basis for that variation is unknow.

Although tropical forage grasses are very important for animal production in the tropics, most (if not all) species can be considered as 'orphan' plants since molecular information is still rare. The developing of GnEd systems in a nongenetic model plants is challenging (Shan et al. 2020). Major bottlenecks for GnEd in tropical forage grasses include the large and usually polyploid genomes of these species whose sequences are not available for most of them (Simeão et al. 2021), and the inexistency or inefficiency of transformation protocols for a number of these species (Bellido et al. 2021). Thus, more scientific developments are needed for GnEd of tropical forage grasses be able to significantly contribute with improvements in animal production.

\section{GnEd to reduce greenhouse gas emission by cattle}

Enteric methane from ruminants has been shown to have a significant contribution to human global greenhouse gas emission (Beauchemin et al. 2020; Opio et al. 2013). As tropical and subtropical regions hold a large ruminant population (Gilbert et al. 2018), one concern is to increase cattle productivity with as low as possible effect on methane emission. Methane in the rumen is 
Table 1 A summary of challenges found in cattle farming in tropical regions and potential contributions of genome editing

\begin{tabular}{|c|c|c|}
\hline Challenges & Genome modifications & Expected contributions \\
\hline High temperature and humidity & $\begin{array}{l}\text { Introduction of SNPs in the prolactin receptor gene } \\
\text { Deletions in the Pre-melanossomal protein } 17 \text { gene } \\
\text { Introduction of heat tolerance SNPS of Bos taurus indicus } \\
\text { in B. taurus taurus cattle }\end{array}$ & Decrease the heat stress in Bos taurus taurus cattle \\
\hline Poor milk yield performance & Introduction of SNPS associated with milk yield & Increase the milk production in B. taurus indicus cattle \\
\hline High ectoparasites infestations & $\begin{array}{l}\text { Disruption of transformer (tra) gene in C. hominovorax } \\
\text { Introduction of tick resistance SNPs of B. taurus indicus in } \\
\text { B. taurus taurus cattle }\end{array}$ & $\begin{array}{l}\text { Control of screwworm infestations } \\
\text { Increase the tolerance to tick infestations in B. taurus taurus } \\
\text { cattle }\end{array}$ \\
\hline Emission of greenhouse gas & $\begin{array}{l}\text { Disruption of methanogenic archaea genes associated } \\
\text { with methane production in the rumem }\end{array}$ & Decrease the cattle methane emission \\
\hline
\end{tabular}

produced by methanogenic archaea as Methanobrevibacter gottschalkii and Mbb. ruminantium, among others (Patra et al. 2017). Those rumen methanogens produce methane by converting $\mathrm{H}_{2}$ and $\mathrm{CO}_{2}$ into $\mathrm{CH}_{4}$ (Lyu et al. 2018). Although there are several attempts to mitigate the rumen methane emission, none is sustainable yet (Islam and Lee 2019).

The GnEd can offer a new opportunity to mitigate the $\mathrm{CH}_{4}$ production in the rumen by manipulating the genome of methanogenic archaea. It was shown that is possible to delete genomic sequences of Methanosarcina acetivorans in order to generate frameshift mutations using Cas9-mediated genome editing and also possible to introduce multiple deletions (Nayak and Metcalf 2017). The genome sequence of $M b b$ ruminantium is available (Leahy et al. 2010) and the function of some predicted gene clusters were shown (Bharathi et al. 2020). Further studies with rumen methanogens are required and will be useful to provide information about genes that play role on $\mathrm{CH}_{4}$ production in the rumen. Then, trough $\mathrm{GnEd}$ will be possible to target multiples candidate genes in order generate mutant methanogens archaea that produce less $\mathrm{CH}_{4}$ and use them to populate the rumen.

\section{Regulatory aspects}

The regulation of GnEd animals is still in discussion in some countries while in others, as Brazil, Argentina and Japan, there is a regulatory policy that can consider GnEd animals that do not contain foreign DNA (i.e. DNA sequences that do not exist in the specie) as non-GMO after case-by-case evaluations (Hallerman et al. 2022). That means that in some countries GnEd animals generated without foreign DNA can be regulated as conventional animals after approval by the respective regulatory agencies while in others the regulation is still unclear. Such discrepancies in the regulatory policies among countries need to be addressed in order to allow a worldwide application and commercialization of GnEd cattle and the derived products.

\section{Conclusion}

GnEd is a genomic tool that can revolutionize cattle production. There are perspectives to apply this technology in order to increase the animal performance under the challenges imposed by the tropical environments (Table 1). The genome editing can be performed in the animal aiming to introduce or to increase the frequency of one or more favorable alleles in a given breed or it can be performed in the species surrounding it, as tropical pastures, parasites and microorganisms, aiming to feed the animal properly and to improve health and quality of life. However, to GnEd accomplish its tasks, several studies need to be carried out in order to identify and increase our knowledge about potential targets, taking into consideration the biodiversity found in a tropical climate. In addition, investigations of unintended genomic modifications are required after every gene editing to avoid further off-targets effects. For last, the regulation of GnEd animals can differ among countries, which can restrain international trade of products derived from GnEd cattle while a worldwide consonant regulatory policy is not established.

\section{Acknowledgements \\ The authors are supported by National Council for Scientific and Technologi- cal Development (CNPq) and Fundacao de Amparo a Pesquisa do Estado de Minas Gerais (Fapemig). We thank Dr Marcelo Bertolini for assistance and comments on the manuscript.}

\section{Authors' contributions}

Both authors contributed equally to the manuscript. Both authors have read and approved the final manuscript.

\section{Funding}

Not applicable.

Availability of data and materials

Not applicable.

\section{Declarations}

Ethics approval and consent to participate Not applicable. 


\section{Consent for publication}

Not applicable.

\section{Competing interests}

The authors declare that they have no competing interest.

\section{Author details}

${ }^{1}$ Animal Reproduction and Biotechnology Laboratory, Embrapa Dairy Cattle, Rua Eugenio do Nascimento, Juiz de Fora, MG 610, Brazil. ${ }^{2}$ Laboratory of Plant Genetics, Embrapa Dairy Cattle, Rua Eugenio do Nascimento, Juiz de Fora, MG 610, Brazil.

\section{Received: 5 November 2021 Accepted: 17 January 2022}

Published online: 14 February 2022

\section{References}

Ahmed MMM, El Amin Al. Effect of hot dry summer tropical climate on forage intake and milk yield in Holstein-Friesian and indigenous zebu cows in Sudan. J Arid Environ. 1997;35(4):737-46. https://doi.org/10.1006/jare. 1996.0181.

Anzures-Olvera F, Véliz FG, de Santiago A, García JE, Mellado J, Macías-Cruz U, et al. The impact of hair coat color on physiological variables, reproductive performance and milk yield of Holstein cows in a hot environment. J Therm Biol. 2019;81:82-8. https://doi.org/10.1016/j.jtherbio.2019.02. 020.

Bauman DE. Bovine somatotropin and lactation: from basic science to commercial application. Domest Anim Endocrinol. 1999;17(2-3):101-16. https://doi.org/10.1016/S0739-7240(99)00028-4.

Beauchemin KA, Ungerfeld EM, Eckard RJ, Wang M. Review: fifty years of research on rumen methanogenesis: lessons learned and future challenges for mitigation. Animal. 2020;14:s2-16. https://doi.org/10.1017/ S1751731119003100.

Bellido AM, Canadá EDS, Permingeat HR, Echenique V. Genetic transformation of apomitic grasses: progress and constrains. Front Plant Sci. 2021;12: 768393. https://doi.org/10.3389/fpls.2021.768393.

Bharathi M, Senthil Kumar N, Chellapandi P. Functional prediction and assignment of Methanobrevibacter ruminantium M1 operome using a combined bioinformatics approach. Front Genetics. 2020. https://doi. org/10.3389/fgene.2020.593990.

Blott S, Kim J-J, Moisio S, Schmidt-Küntzel A, Cornet A, Berzi P, et al. Molecular dissection of a quantitative trait locus: a phenylalanine-to-tyrosine substitution in the transmembrane domain of the bovine growth hormone receptor is associated with a major effect on milk yield and composition. Genetics. 2003;163(1):253-66. https://doi.org/10.1093/ genetics/163.1.253.

Camargo LSA, Aguirre-Lavin T, Adenot P, Araujo TD, Mendes VRA, et al. Heat shock during in vitro maturation induces chromatin modifications in the bovine embryo. Reproduction. 2019;158(4):313-22. https://doi.org/ 10.1530/REP-19-0245.

Carvalheira LD, Wenceslau RR, Ribeiro LD, de Carvalho BC, Borges ÁM, Camargo LS. Daily vaginal temperature in Girolando cows from three different genetic composition under natural heat stress. Transl Anim Sci. 2021. https://doi.org/10.1093/tas/txab138.

Chaverra-Rodriguez D, Macias VM, Hughes GL, Pujhari S, Suzuki Y, Peterson DR, et al. Targeted delivery of CRISPR-Cas9 ribonucleoprotein into arthropod ovaries for heritable germline gene editing. Nat Commun. 2018;9(1):3008. https://doi.org/10.1038/s41467-018-05425-9.

Cong L, Ran FA, Cox D, Lin S, Barretto R, Habib N, et al. Multiplex genome engineering using CRISPR/Cas systems. Science. 2013;339(6121):819-23. https://doi.org/10.1126/science.1231143.

Corl BA, Baumgard LH, Dwyer DA, Griinari JM, Phillips BS, Bauman DE. The role of $\Delta 9$-desaturase in the production of cis-9, trans-11 CLA. J Nutr Biochem. 2001;12(11):622-30. https://doi.org/10.1016/S0955-2863(01) 00180-2.

Costa-Júnior LM, Chaves DP, Brito DRB, Santos VAF, Costa-Júnior HN, Barros ATM. A review on the occurrence of Cochliomyia hominivorax (Diptera: Calliphoridae) in Brazil. Rev Bras Parasitol Vet. 2019;28(4):548-62. https:// doi.org/10.1590/s1984-29612019059. de la Fuente J. Controlling ticks and tick-borne diseases... looking forward. Ticks Tick Borne Dis. 2018;9(5):1354-7. https://doi.org/10.1016/j.ttbdis 2018.04.001.

Deinum B, Sulastri RD, Zeinab MHJ, Maassen A. Effects of light intensity on growth, anatomy and forage quality of two tropical grasses (Brachiaria brizantha and Panicum maximum var. trichoglume). Neth J Agric Sci. 1996:44(2):111-24. https://doi.org/10.18174/njas.v44i2.551.

Delgado-Pertíñez M, Horcada A. Better animal feeding for improving the quality of ruminant meat and dairy. Foods. 2021;10(5):1076. https://doi.org/ 10.3390/foods 10051076.

Dikmen S, Khan FA, Huson HJ, Sonstegard TS, Moss JI, Dahl GE, Hansen PJ. The SLICK hair locus derived from Senepol cattle confers thermotolerance to intensively managed lactating Holstein cows. J Dairy Sci. 2014;97(9):5508-20. https://doi.org/10.3168/jds.2014-8087.

Dilzer A, Park Y. Implication of conjugated linoleic acid (CLA) in human health. Crit Rev Food Sci Nutr. 2012;52(6):488-513. https://doi.org/10.1080/ 10408398.2010.501409.

dos Santos MM, Souza-Junior JBF, Dantas MRT, de Macedo Costa LL. An updated review on cattle thermoregulation: physiological responses, biophysical mechanisms, and heat stress alleviation pathways. Environ Sci Pollut Res. 2021;28(24):30471-85. https://doi.org/10.1007/ s11356-021-14077-0.

El-Nahas A. Variation in the genetic effects of ABCG2, growth hormone and growth hormone receptor gene polymorphisms on milk production traits in Egyptian native, holstein and hybrid cattle populations. Pak Vet J. 2018;38(04):371-6. https://doi.org/10.29261/pakvetj/2018.089.

EMBRAPA. Balanço social. 2020. https://www.embrapa.br/balanco-social-2020. Accessed 28 Oct 2021.

Feng X, López Del Amo V, Mameli E, Lee M, Bishop AL, Perrimon N, Gantz VM. Optimized CRISPR tools and site-directed transgenesis towards gene drive development in Culex quinquefasciatus mosquitoes. Nat Commun. 2021;12(1):2960. https://doi.org/10.1038/s41467-021-23239-0.

Ferreira RC, Lara LA, Chiari L, Barrios SCL, do Valle CB, Valério JR, et al. Genetic mapping with allele dosage information in Tetraploid Urochloa decumbens (Stapf) R. D. Webster reveals insights into Spittlebug (Notozulia entreriana Berg) resistance. Front Plant Sci. 2019. https://doi.org/10. 3389/fpls.2019.00092.

Freitas A, Souza G, Camargo G, Peixoto G, MRS C, Tonhati H. Characterization of stearoil-CoA desaturase gene in Gir and Guzerá breed. In: Simposio Brasileiro de Melhoramento Animal, X, Uberaba, 2013. http://girleiteiro. org.br/arquivos/1785.pdf. Accessed 28 Oct 2021.

Garcia AB, Angeli N, Machado L, de Cardoso FC, Gonzalez F. Relationships between heat stress and metabolic and milk parameters in dairy cows in southern Brazil. Trop Anim Health Prod. 2015;47(5):889-94. https:// doi.org/10.1007/s11250-015-0804-9.

Gilbert M, Nicolas G, Cinardi G, Van Boeckel TP, Vanwambeke SO, Wint GRW, Robinson TP. Global distribution data for cattle, buffaloes, horses, sheep, goats, pigs, chickens and ducks in 2010. Sci Data. 2018;5(1): 180227. https://doi.org/10.1038/sdata.2018.227.

Grisi L, Leite RC, Martins JR, Barros AT, Andreotti R, Cançado PH, León AA, Pereira JB, Villela HS. Reassessment of the potential economic impact of cattle parasites in Brazil. Rev Bras Parasitol Vet. 2014;23(2):150-6. https:// doi.org/10.1590/S1984-29612014042.

Guenni O, Seiter S, Figueroa R. Growth responses of three Brachiaria species to light intensity and nitrogen supply. Trop Grassl. 2008;42:75-87.

Guimarães JD, Alves NG, Costa EP, Silva MR, Costa FMJ, Zamperlini B. Eficiências reprodutiva e produtiva em vacas das raças Gir, Holandês e Cruzadas Holandês x Zebu. Rev Bras Zootec. 2002;31(2):641-7. https://doi.org/10. 1590/S1516-35982002000300014.

Hallerman EM, Bredlau JP, Camargo LSA, Dagli MLZ, Karembu M, Ngure G, Romero-Aldemita R, Rocha-Salavarrieta PJ, Tizard M, Walton M, WrayCahen D. Towards progressive regulatory approaches for agricultural applications of animal biotechnology. Transgenic Res. 2022. https://doi. org/10.1007/s11248-021-00294-3.

Hanley SJ, Pellny TK, de Vega JJ, Castiblanco V, Arango J, Eastmond PJ, et al. Allele mining in diverse accessions of tropical grasses to improve forage quality and reduce environmental impact. Ann Bot. 2021;128(5):627-37. https://doi.org/10.1093/aob/mcab101.

Hansen PJ. Effects of heat stress on mammalian reproduction. Philos Trans $\mathrm{R}$ Soc B Biol Sci. 2009;364(1534):3341-50. https://doi.org/10.1098/rstb. 2009.0131. 
Hansen PJ. Genetic variation in resistance of the preimplantation bovine embryo to heat shock. Reprod Fertil Dev. 2015;27(1):22. https://doi.org/ 10.1071/RD14311.

Hansen PJ. Prospects for gene introgression or gene editing as a strategy for reduction of the impact of heat stress on production and reproduction in cattle. Theriogenology. 2020;154:190-202. https://doi.org/10.1016/j. theriogenology.2020.05.010

Hayhoe K, Cayan D, Field CB, Frumhoff PC, Maurer EP, Miller NL. Emissions pathways, climate change, and impacts on California. Proc Natl Acad Sci. 2004;101(34):12422-7. https://doi.org/10.1073/pnas.0404500101.

Henry BK, Eckard RJ, Beauchemin KA. Review: adaptation of ruminant livestock production systems to climate changes. Animal. 2018;12:s445-56. https://doi.org/10.1017/S1751731118001301

Hickey JM, Bruce C, Whitelaw A, Gorjanc G. Promotion of alleles by genome editing in livestock breeding programmes. J Anim Breed Genet. 2016;133(2):83-4. https://doi.org/10.1111/jbg.12206.

Hillman PE, Lee CN, Carpenter JR, Baek KS, Parkhurst A. Impact of Hair Color on Thermoregulation of Dairy Cows to Direct Sunlight. In 2001 Sacramento, CA July 29-August 1,2001. St. Joseph, MI: American Society of Agricultural and Biological Engineers. 2001. https://doi.org/10.13031/ 2013.23648

Huson HJ, Kim E-S, Godfrey RW, Olson TA, McClure MC, Chase CC. Genomewide association study and ancestral origins of the slick-hair coat in tropically adapted cattle. Front Genetics. 2014. https://doi.org/10.3389/ fgene.2014.00101

Islam M, Lee S-S. Advanced estimation and mitigation strategies: a cumulative approach to enteric methane abatement from ruminants. J Anim Sci Technol. 2019;61(3):122-37. https://doi.org/10.5187/jast.2019.61.3.122.

Isola JVV, Menegazzi G, Busanello M, dos Santos SB, Agner HSS, Sarubbi J. Differences in body temperature between black-and-white and red-and-white Holstein cows reared on a hot climate using infrared thermography. J Therm Biol. 2020;94: 102775. https://doi.org/10.1016/j. jtherbio.2020.102775.

Jank L, Barrios SC, do Valle CB, Simeão RM, Alves GF. The value of improved pastures to Brazilian beef production. Crop Pasture Sci. 2014;65(11):1132. https://doi.org/10.1071/CP13319.

Jenko J, Gorjanc G, Cleveland MA, Varshney RK, Whitelaw CBA, Woolliams JA, Hickey JM. Potential of promotion of alleles by genome editing to improve quantitative traits in livestock breeding programs. Genet Sel Evol. 2015;47(1):55. https://doi.org/10.1186/s12711-015-0135-3.

Jones C, De Vega J, Worthington M, Thomas A, Gasior D, Harper J, et al. A comparison of differential gene expression in response to the onset of water stress between three hybrid brachiaria genotypes. Front Plant Sci. 2021. https://doi.org/10.3389/fpls.2021.637956.

Jongejan F, Uilenberg G. The global importance of ticks. Parasitology. 2004;129(S1):S3-14. https://doi.org/10.1017/S0031182004005967.

Key N, Sneeringer S. Potential effects of climate change on the productivity of U.S. dairies. Am J Agric Econ. 2014;96(4):1136-56. https://doi.org/10. 1093/ajae/aau002.

Kgwatalala PM, Kgwatalala PM, Ibeagha-Awemu EM, Kgwatalala PM, Ibeagha-Awemu EM, Hayes JF. Single nucleotide polymorphisms in the open reading frame of the stearoyl-CoA desaturase gene and resulting genetic variants in Canadian Holstein and Jersey cows. DNA Seq. 2007;18(5):357-62. https://doi.org/10.1080/10425170701291921.

Koba K, Yanagita T. Health benefits of conjugated linoleic acid (CLA). Obes Res Clin Pract. 2014;8(6):e525-32. https://doi.org/10.1016/j.orcp.2013.10. 001.

Laible G, Cole SA, Brophy B, Wei J, Leath S, Jivanji S. Holstein Friesian dairy cattle edited for diluted coat color as adaptation to climate change. BioRxiv. 2020. https://doi.org/10.1101/2020.09.15.298950.

Leahy SC, Kelly WJ, Altermann E, Ronimus RS, Yeoman CJ, Pacheco DM. The genome sequence of the Rumen Methanogen Methanobrevibacter ruminantium reveals new possibilities for controlling ruminant methane emissions. PLoS ONE. 2010;5(1): e8926. https://doi.org/10.1371/ journal.pone.0008926.

Lyu Z, Shao N, Akinyemi T, Whitman WB. Methanogenesis. Curr Biol. 2018;28(13):R727-32. https://doi.org/10.1016/j.cub.2018.05.021.

Macias VM, McKeand S, Chaverra-Rodriguez D, Hughes GL, Fazekas A, Pujhari S. Cas9-mediated gene-editing in the malaria mosquito Anopheles stephensi by ReMOT Control. G3. 2020;10(4):1353-60. https://doi.org/ 10.1534/g3.120.401133
Mariasegaram M, Chase CC, Chaparro JX, Olson TA, Brenneman RA, Niedz RP. The slick hair coat locus maps to chromosome 20 in Senepol-derived cattle. Anim Genet. 2007;38(1):54-9. https://doi.org/10.1111/j.13652052.2007.01560.X.

Mauger G, Bauman Y, Nennich T, Salathé E. Impacts of climate change on milk production in the United States. Prof Geogr. 2015;67(1):121-31. https:// doi.org/10.1080/00330124.2014.921017.

McCarty NS, Graham AE, Studená L, Ledesma-Amaro R. Multiplexed CRISPR technologies for gene editing and transcriptional regulation. Nat Commun. 2020;11(1):1281. https://doi.org/10.1038/s41467-020-15053-x.

Miranda, J, Freitas, A. Raças e tipos de cruzamento para produção de leite. Embrapa. 2009. https://ainfo.cnptia.embrapa.br/digital/bitstream/item/ 65294/1/CT-98-Racas-e-tipos-de-cruzamentos.pdf. Accessed 28 Oct 2021.

Moscovici Joubran A, Pierce KM, Garvey N, Shalloo L, O'Callaghan TF. Invited review: a 2020 perspective on pasture-based dairy systems and products. J Dairy Sci. 2021;104(7):7364-82. https://doi.org/10.3168/jds. 2020-19776.

Mota RR, Silva FF, Lopes PS, Tempelman RJ, Sollero BP, Aguilar I, Cardoso FF. Analyses of reaction norms reveal new chromosome regions associated with tick resistance in cattle. Animal. 2018;12(2):205-14. https://doi.org/ 10.1017/S1751731117001562.

Muktar MS, Habte E, Teshome A, Assefa Y, Negawo AT, Lee KW, et al. Insights into the genetic architecture of complex traits in Napier grass (Cenchrus purpureus) and QTL regions governing forage biomass yield, water use efficiency and feed quality traits. Front Plant Sci. 2022;12: 678862. https://doi.org/10.3389/fpls.2021.678862.

Nardone A, Ronchi B, Lacetera N, Ranieri MS, Bernabucci U. Effects of climate changes on animal production and sustainability of livestock systems. Livest Sci. 2010;130(1-3):57-69. https://doi.org/10.1016/j.livsci.2010.02. 011.

Nayak DD, MetcalfWW. Cas9-mediated genome editing in the methanogenic archaeon Methanosarcina acetivorans. Proc Natl Acad Sci. 2017;114(11):2976-81. https://doi.org/10.1073/pnas.1618596114.

Oke OE, Uyanga VA, lyasere OS, Oke FO, Majekodunmi BC, Logunleko MO, et al. Environmental stress and livestock productivity in hot-humid tropics: alleviation and future perspectives. J Therm Biol. 2021;100: 103077. https://doi.org/10.1016/j.jtherbio.2021.103077.

Olson TA, Lucena C, Chase CC, Hammond AC. Evidence of a major gene influencing hair length and heat tolerance in Bos taurus cattle. J Anim Sci. 2003;81(1):80-90. https://doi.org/10.2527/2003.81180x.

Opio C, Gerber P, Mottet A, Falcucci A, Tempio G, MacLeod M et al. Greenhouse gas emissions from ruminant supply chains - a global life cycle assessment. FAO 2013. http://www.fao.org/3/i3461e/i3461e.pdf. Accessed 28 Oct 2021.

Otto PI, Guimarães SEF, Verardo LL, Azevedo ALS, Vandenplas J, Soares ACC, et al. Genome-wide association studies for tick resistance in Bos taurus $\times$ Bos indicus crossbred cattle: a deeper look into this intricate mechanism. J Dairy Sci. 2018;101(12):11020-32. https://doi.org/10.3168/jds. 2017-14223.

Panetto J, Silva MV, Verneque RS, Machado MA, Fernandes A, Martins MF et al. Programa Nacional de Melhoramento do Gir Leiteiro - Sumário Brasileiro de Touros - Resultado do Teste de Progênie - Maio 2020. https:// www.embrapa.br/busca-de-publicacoes/-/publicacao/1122049/progr ama-nacional-de-melhoramento-do-gir-leiteiro-sumario-brasileirode-touros---3-avaliacao-genomica-de-touros---resultado-do-teste-deprogenie---maio-2020. Accessed 28 Oct 2021.

Patra A, Park T, Kim M, Yu Z. Rumen methanogens and mitigation of methane emission by anti-methanogenic compounds and substances. J Anim Sci Biotechnol. 2017;8(1):13. https://doi.org/10.1186/ s40104-017-0145-9.

Paula-Lopes F, Al-Katanani Y, Rivera R, Tekin S, Majewski A, Ocon O, et al. Genetic divergence in cellular resistance to heat shock in cattle: differences between breeds developed in temperate versus hot climates in responses of preimplantation embryos, reproductive tract tissues and lymphocytes to increased culture temperatures. Reproduction. 2003. https://doi.org/10.1530/rep.0.1250285.

Paulo DF, Williamson ME, Arp AP, Li F, Sagel A, Skoda SR, et al. Specific gene disruption in the major livestock pests Cochliomyia hominivorax and Lucilia cuprina using CRISPR/Cas9. G3. 2019;9(9):3045-55. https://doi. org/10.1534/g3.119.400544. 
Pauly M, Keegstra K. Biosynthesis of the plant cell wall matrix polysaccharide xyloglucan. Annu Rev Plant Biol. 2016;67(1):235-59. https://doi.org/10. 1146/annurev-arplant-043015-112222.

Pereira JF, Azevedo ALS, Pessoa-Filho M, Romanel EAC, Pereira AV, Vigna BBZ, et al. Research priorities for next-generation breeding of tropical forages in Brazil. Crop Breed Appl Biotechnol. 2018;18(3):314-9. https:// doi.org/10.1590/1984-70332018v18n3n46.

Pereira JF, Cunha GR, Moresco ER. Improved drought tolerance in wheat is required to unlock the production potential of the Brazilian Cerrado. Crop Breed Appl Biotechnol. 2019;19:217-25. https://doi.org/10.1590/ 1984-70332019v19n2r30.

Plath-Gabler A, Gabler C, Sinowatz F, Berisha B, Schams D. The expression of the IGF family and GH receptor in the bovine mammary gland. J Endocrinol. 2001;168(1):39-48. https://doi.org/10.1677/joe.0.1680039.

Porto-Neto LR, Bickhart DM, Landaeta-Hernandez AJ, Utsunomiya YT, Pagan $\mathrm{M}$, Jimenez $\mathrm{E}$, et al. Convergent evolution of slick coat in cattle through truncation mutations in the prolactin receptor. Front Genetics. 2018. https://doi.org/10.3389/fgene.2018.00057.

Rahmatalla SA, Müller U, Strucken EM, Reissmann M, Brockmann GA. The F279Y polymorphism of the GHR gene and its relation to milk production and somatic cell score in German Holstein dairy cattle. J Appl Genet. 2011;52(4):459-65. https://doi.org/10.1007/s13353-011-0051-3.

Ramesha K, Rao A, Basavaraju M, Geetha G, Kataktalware M, Jeyakumar S. Genetic variability of bovine GHR, IGF-1 and IGFBP-3 genes in Indian cattle and buffalo. S Afr J Anim Sci. 2016;45(5):485. https://doi.org/10. 4314/sajas.v45i5.5.

Rashid M, Rashid MI, Akbar H, Ahmad L, Hassan MA, Ashraf K, et al. A systematic review on modelling approaches for economic losses studies caused by parasites and their associated diseases in cattle. Parasitology. 2019;146(2):129-41. https://doi.org/10.1017/S0031182018001282.

Rensis FD, Scaramuzzi RJ. Heat stress and seasonal effects on reproduction in the dairy cow - a review. Theriogenology. 2003;60(6):1139-51. https:// doi.org/10.1016/S0093-691X(03)00126-2.

Ringseis R, Eder K. Influence of conjugated linoleic acids on functional properties of vascular cells. Br J Nutr. 2009;102(8):1099-116. https://doi.org/10. 1017/S0007114509990304.

Rocha JR, Marçal TS, Salvador FV, Da Silva AC, Carneiro PCS, de Resende MDV, et al. Unraveling candidate genes underlying biomass digestibility in elephant grass (Cenchrus purpureus). BMC Plant Biol. 2019;19(1):548. https://doi.org/10.1186/s12870-019-2180-5.

Salgado LR, Lima R, Santos BF, Shirakawa KT, Vilela MA, Almeida NF, et al. De novo RNA sequencing and analysis of the transcriptome of signalgrass (Urochloa decumbens) roots exposed to aluminum. Plant Growth Regul. 2017:83(1):157-70. https://doi.org/10.1007/s10725-017-0291-2.

Sansbury BM, Wagner AM, Tarcic G, Barth S, Nitzan E, Goldfus R, et al. CRISPRdirected gene editing catalyzes precise gene segment replacement in vitro enabling a novel method for multiplex site-directed mutagenesis. CRISPR J. 2019;2(2):121-32. https://doi.org/10.1089/crispr.2018.0054.

Santos PM, Cruz PG, Araujo LC, Pezzopane JRM, Valle CB, Pezzopane CG. Response mechanisms of Brachiaria brizantha cultivars to water deficit stress. Rev Bras Zootec. 2013;42(11):767-73. https://doi.org/10.1590/ S1516-35982013001100001.

Saraiva NB, Auad AM, Barros E, Coutinho FS, Pereira JF, Barros RA, Ramos HJO, Oliveira MGA. Proteins from eggs of the spittlebug Mahanarva spectabilis (Hemiptera: Cercopidae) reveal clues about its diapause regulation. Bull Entomol Res. 2022. https://doi.org/10.1017/S0007485321000754.

Schennink A, Heck JML, Bovenhuis H, Visker MHPW, van Valenberg HJF, van Arendonk JAM. Milk fatty acid unsaturation: genetic parameters and effects of stearoyl-CoA desaturase (SCD1) and acyl COA: diacylglycerol acyltransferase 1 (DGAT1). J Dairy Sci. 2008;91(5):2135-43. https://doi. org/10.3168/jds.2007-0825.

Schmutz SM, Dreger DL. Interaction of MC1R and PMEL alleles on solid coat colors in Highland cattle. Anim Genet. 2013;44(1):9-13. https://doi.org/ 10.1111/j.1365-2052.2012.02361.x.

Scott MJ, Concha C, Welch JB, Phillips PL, Skoda SR. Review of research advances in the screwworm eradication program over the past 25 years. Entomol Exp Appl. 2017;164(3):226-36. https://doi.org/10.1111/ eea.12607.

Shan S, Soltis PS, Soltis DE, Yang B. Considerations in adapting CRISPR/Cas9 in nongenetic model plant systems. Appl Plant Sci. 2020. https://doi.org/ 10.1002/aps3.11314
Silva TGF, Moura MSB, Sá IIS, Zolnier S, Turco SHN, Souza LSB. Cenários de mudanças climáticas e seus impactos na produção leiteira em estados nordestinos. Rev Brasil Eng Agríc Ambient. 2010;14(8):863-70. https:// doi.org/10.1590/S1415-43662010000800011.

Simeão RM, Resende MDV, Alves RS, Pessoa-Filho M, Azevedo ALS, Jones CS, et al. Genomic selection in tropical forage grasses: current status and future applications. Front Plant Sci. 2021. https://doi.org/10.3389/fpls. 2021.665195 .

Summer A, Lora I, Formaggioni P, Gottardo F. Impact of heat stress on milk and meat production. Anim Front. 2019;9(1):39-46. https://doi.org/10.1093/ af/vfy026.

Svennersten-Sjaunja K, Olsson K. Endocrinology of milk production. Domest Anim Endocrinol. 2005;29(2):241-58. https://doi.org/10.1016/j.doman iend.2005.03.006.

Takahashi M. Heat stress on reproductive function and fertility in mammals. Reprod Med Biol. 2012;11(1):37-47. https://doi.org/10.1007/ s12522-011-0105-6.

Thornton PK, van de Steeg J, Notenbaert A, Herrero M. The impacts of climate change on livestock and livestock systems in developing countries: a review of what we know and what we need to know. Agric Syst. 2009;101(3):113-27. https://doi.org/10.1016/j.agsy.2009.05.002.

Viana JHM, Figueiredo ACS, Gonçalves RLR, Siqueira LGB. A historical perspective of embryo-related technologies in South America. Anim Reprod. 2018;15(Suppl 1):963-70. https://doi.org/10.21451/ 1984-3143-AR2018-0016.

Viitala S, Szyda J, Blott S, Schulman N, Lidauer M, Mäki-Tanila A, et al. The role of the bovine growth hormone receptor and prolactin receptor genes in milk, fat and protein production in Finnish Ayrshire dairy cattle. Genetics. 2006;173(4):2151-64. https://doi.org/10.1534/genetics.105.046730.

Walsberg GE. Consequences of skin color and fur properties for solar heat gain and ultraviolet irradiance in two mammals. J Comp Physiol B. 1988;158(2):213-21. https://doi.org/10.1007/BF01075835.

United Nations, Department of Economic and Social Affairs P.D. World Population Prospects 2019: highlights (ST/ESA/SER.A/423). 2019. https:// population.un.org/wpp/Publications/Files/WPP2019_Highlights.pdf. Accessed 29 Oct 2021.

Wyss JH. Screwworm eradication in the Americas. Ann N Y Acad Sci. 2006;916(1):186-93. https://doi.org/10.1111/j.1749-6632.2000.tb052 89.x.

Zhang M, Dunshea FR, Warner RD, DiGiacomo K, Osei-Amponsah R, Chauhan SS. Impacts of heat stress on meat quality and strategies for amelioration: a review. Int J Biometeorol. 2020;64(9):1613-28. https://doi.org/10. 1007/s00484-020-01929-6.

Zhou Y, Akers RM, Jiang H. Growth hormone can induce expression of four major milk protein genes in transfected MAC-T cells. J Dairy Sci. 2008;91(1):100-8. https://doi.org/10.3168/jds.2007-0509.

\section{Publisher's Note}

Springer Nature remains neutral with regard to jurisdictional claims in published maps and institutional affiliations.

$$
\begin{aligned}
& \text { Ready to submit your research? Choose BMC and benefit from: } \\
& \text { - fast, convenient online submission } \\
& \text { - thorough peer review by experienced researchers in your field } \\
& \text { - rapid publication on acceptance } \\
& \text { - support for research data, including large and complex data types } \\
& \text { - gold Open Access which fosters wider collaboration and increased citations } \\
& \text { - maximum visibility for your research: over } 100 \mathrm{M} \text { website views per year }
\end{aligned}
$$

\section{At $\mathrm{BMC}$, research is always in progress.}

Learn more biomedcentral.com/submissions 